OPEN ACCESS

Edited by:

Micaela Sgorbini,

University of Pisa, Italy

Reviewed by:

Enrico Fiore

University of Padua, Italy

Guanshi Zhang,

University of Texas Health Science Center at San Antonio, United States

*Correspondence:

Jinho Park

jpark@jbnu.ac.kr

Specialty section:

This article was submitted to Comparative and Clinical Medicine, a section of the journal

Frontiers in Veterinary Science

Received: 10 September 2021 Accepted: 06 October 2021

Published: 12 November 2021

Citation:

Ha S, Kang S, Han M, Lee J, Chung H, Kim D and Park J (2021)

Therapeutic Effects of Levocarnitine or

Vitamin B Complex and E With Selenium on Glycerin-Treated Holstein

Friesian Cows With Clinical Ketosis.

Front. Vet. Sci. 8:773902.

doi: 10.3389/fvets.2021.773902

\section{Therapeutic Effects of Levocarnitine or Vitamin B Complex and E With Selenium on Glycerin-Treated Holstein Friesian Cows With Clinical Ketosis}

\author{
Seungmin $\mathrm{Ha}^{1}$, Seogjin Kang ${ }^{1}$, Manhye Han ${ }^{1}$, Jihwan Lee ${ }^{1}$, Hakjae Chung ${ }^{1}$, \\ Donghyeon Kim ${ }^{1}$ and Jinho Park ${ }^{2 *}$
}

${ }^{1}$ National Institute of Animal Science, RDA, Cheonan-si, South Korea, ${ }^{2}$ College of Veterinary Medicine, Jeonbuk National University, Iksan-si, South Korea

Currently, ketosis has no fully satisfactory resolution in dairy cows. Here, we investigated the effect of levocarnitine or vitamin B complex and $E$ with selenium on clinically ketotic cows ( $\beta$-hydroxybutyrate $\geq 3.0 \mathrm{mmol} / \mathrm{L}$ and decreased milk yield), fed glycerin. In total, 18 cases of Holstein cows with clinical ketosis during the postpartum transition period were randomly assigned to three treatments ( 6 cases per group): (1) levocarnitine $(C+G)$, (2) vitamin B complex and $E$ with selenium $(V B E S+G)$, and (3) levocarnitine and vitamin $\mathrm{B}$ complex and $\mathrm{E}$ with selenium $(\mathrm{C}+\mathrm{VBES}+\mathrm{G})$. All groups were administered glycerin. Treatments were administered daily for 4 days. Blood sampling was performed on the onset day of ketosis (day 0 ), day 4 , and day $6 . \beta$-Hydroxybutyrate (BHBA), milk yield (MY), and serum biochemical values were measured. Half of the animals in $C+G$ failed to overcome clinical ketosis. VBES $+\mathrm{G}$ treatment ameliorated BHBA $(p<0.05), \mathrm{MY}$, and glucose on day 4. However, ketosis was exacerbated following the discontinuation of the treatment. $\mathrm{C}+\mathrm{VBES}+\mathrm{G}$ treatment improved BHBA, glucose $(p<0.05)$, and $\mathrm{MY}$ and reduced ketotic cases on days 4 and 6 with greater improvements compared to the others. In conclusion, combined treatment with levocarnitine, vitamin B complex and $\mathrm{E}$ with selenium, and glycerin may have the therapeutic effect on clinical ketosis.

Keywords: therapeutic effect, clinical ketosis, levocarnitine, vitamin B, vitamin E, selenium, glycerin, dairy cattle

\section{INTRODUCTION}

Ketosis, which is caused by negative energy balance, is a common metabolic disorder during the postpartum transition period in dairy cows. All dairy cattle experience negative energy balance in the early lactation period, which stimulates non-esterified fatty acids (NEFA) release from the adipose tissues to the blood stream $(1,2)$. NEFA is relatively distributed into one of the three types of metabolism, ATP by complete oxidation, ketone synthesis by incomplete oxidation, triglyceride (TG) production by re-esterification. The incidence of ketosis depends on the extent of lipolysis and tolerance of cows $(1,3)$.

Ketosis affects global dairy industry. Studies have reported various treatments for ketosis including single or combined use of energy sources (dextrose, propylene glycol, glycerin), 
pharmacological substances (glucocorticoids, insulin, etc.), and nutritional supplements (amino acids, vitamin B, phosphorus, etc.) (4-15). However, these treatments have ambiguous or side effects and there is limited evidence to support their continued use. Dextrose was not a good treatment option for ketosis, because its effect ends within a day, ketosis recurs, and electrolyte imbalance occurs due to the excretion of surplus glucose via the kidneys $(16,17)$. Glucocorticoids pose the risk of adverse effects, and their effects are ambiguous; therefore, glucocorticoids are not recommended to treat ketosis. Insulin therapy has limited evidence and is rather expensive. In addition, it is unclear whether phosphorus is necessary for treating ketosis (3).

Single usage of glucogenic precursors (propylene glycol and glycerin) was effective against ketosis, but combination treatments using glucose precursors are more effective than their single usage (18-20). A previous study reported that combination of levocarnitine and methionine with propylene glycol improved ketosis more effectively than propylene glycol alone. However, the study had several limitations and the cases were retreated due to the lack of improvement. Furthermore, the effect of levocarntine and methionine with propylene glycol might not be precise because the treatment product includes amino acids and vitamin $\mathrm{B}$, which influence the ketosis-related metabolism (15).

Glycerin is converted to glucose via the rumen and liver while exerting less toxic effects than propylene glycol (21). Recently, surplus production of glycerin from biodiesel fuel production has reduced its high cost, which makes glycerin an attractive energy ingredient. A previous study reported the effect of combining glycerin with glucagon (22). Glucagon has limited evidence of efficacy and is expensive, similar to insulin. It is still unclear which combination with glycerin is adequate for ketosis treatment.

Amino acids, vitamins, and trace minerals are known to enhance the performance and production of dairy cattle. Levocarnitine is an amino acid with quaternary ammonium, and previously, it was called vitamin $\mathrm{B}_{4}$. Carnitine plays vital roles in ameliorating fatty acid metabolism by transporting fatty acids into the mitochondria, supporting the immune system, enhancing the antioxidant system, and improving the reproductive system $(23,24)$. Vitamin B is synthesized by microflora in the rumen; therefore, mature ruminant animals do not require exogenous vitamin B. However, in dairy cattle with high milk production, studies have demonstrated the beneficial effects of thiamine $(25)$, niacin $(26,27)$, biotin $(28)$, and folic acid (29). The vitamin B complex participates in metabolism as cofactors or coenzymes, for instance, in the TCA cycle in the mitochondria and the folate, glutathione, and methionine cycles in the cytosol (30). Vitamin E, distributed from the liver to the body after being absorbed and transported from the intestine to the liver, acts as an antioxidant $(31,32)$. Deficiency of vitamin $\mathrm{E}$ and selenium is associated with nutritional myopathy, reduced fertility, retained placenta, metritis, and mastitis, whereas selenium enhances antioxidant properties, immune cells, and embryo survival $(33,34)$. These supplements improve impaired liver functions.
TABLE 1 | Ingredients and nutrients of total mixed rations used in this study.

\begin{tabular}{|c|c|}
\hline Item & Amount \\
\hline \multicolumn{2}{|c|}{ Ingredients composition, \% of DM } \\
\hline Concentrate & 15.32 \\
\hline Soybean meal & 2.36 \\
\hline Corn silage & 47.13 \\
\hline Alfalfa hay & 7.07 \\
\hline Tall fescue & 9.43 \\
\hline Timothy & 5.89 \\
\hline Energy booster ${ }^{a}$ & 7.07 \\
\hline Cash gold ${ }^{a}$ & 4.71 \\
\hline Sodium Bicarbonate & 0.12 \\
\hline Limestone & 0.16 \\
\hline Zin care ${ }^{a}$ & 0.12 \\
\hline Supex- $F^{a}$ & 0.47 \\
\hline Dairyman ${ }^{b}$ & 0.05 \\
\hline Trace minerals ${ }^{c}$ & 0.06 \\
\hline Vitamin premix ${ }^{d}$ & 0.06 \\
\hline \multicolumn{2}{|l|}{ Chemical composition } \\
\hline Dry matter (DM), \% & 53.2 \\
\hline Crude protein, \% of DM & 12.4 \\
\hline Neutral detergent fiber, \% of DM & 30.8 \\
\hline Acid detergent fiber, \% of DM & 18.8 \\
\hline Calcium, \% of DM & 0.4 \\
\hline Phosphorus, \% of DM & 0.15 \\
\hline
\end{tabular}

${ }^{a}$ Cofavet, Cheonan, Republic of Korea.

${ }^{b}$ Farmtec, Chungju, Republic of Korea.

${ }^{c}$ Contained $0.40 \% \mathrm{Mg}, 0.20 \% \mathrm{~K}, 4.00 \% \mathrm{~S}, 0.08 \% \mathrm{Na}, 0.03 \% \mathrm{Cl}, 400 \mathrm{mg}$ of $\mathrm{Fe} / \mathrm{kg}$, $60,042 \mathrm{mg}$ of $\mathrm{Zn} / \mathrm{kg}, 16,125 \mathrm{mg}$ of $\mathrm{Cu} / \mathrm{kg}$, and $42,375 \mathrm{mg}$ of $\mathrm{Mn} / \mathrm{kg}$.

${ }^{d}$ Provided $\sim 5,000 \mathrm{KIU}$ of vitamin A/kg, 1,000 KIU of vitamin $\mathrm{D} / \mathrm{kg}, 33,500 \mathrm{mg}$ of vitamin $\mathrm{E} / \mathrm{kg}$, and 2,400 mg of vitamin $\mathrm{C} / \mathrm{kg}$.

In this study, we aimed to find an effective combination therapy using glycerin and hypothesized that clinical ketosis could be resolved by stimulating the influx of fatty acids into the mitochondria of hepatic cells (levocarnitine), improving metabolic progress with reducing oxidative stress (vitamin B complex and E with selenium), and supplying a precursor for glucose synthesis (glycerin). Thus, the objective of this study was to determine the effect of levocarnitine or vitamin B complex and E with selenium on the resolution of clinically ketotic cows that were fed glycerin in the context of improved BHBA, glucose, milk yield, and serum biochemical values. The findings could help establish a strategy to overcome or prevent ketosis.

\section{MATERIALS AND METHODS}

\section{Animals}

The present study was conducted in a farm in the National Institute of Animal Science in Cheonan, Republic of Korea, using a total of 18 cases of Holstein Friesian cows with clinical ketosis. The cows had no other diseases. The cows were raised in a loose housing system and calved from March 2018 to 
January 2021. The cows were fed total mixed rations ad libitum (Table 1). They were milked twice a day, in the morning and evening.

\section{Blood Sampling and Study Design}

Blood was sampled from the jugular vein of the cows once every 3 days during the postcalving periparturient period ( 8 times for 21 days from calving date), when the cows began to be fed as soon as they finished milking in the morning. Blood was collected with serum-separating tube (SST) tubes. $\beta$-Hydroxybutyrate (BHBA) was measured using electronic handheld meters (FreeStyle Optimum Neo, Abbott Diabetes Care Ltd., Witney, UK) and $\beta$-ketone test strips (FreeStyle Optimum H $\beta$-ketone, Abbott Diabetes Care Ltd., Witney, UK) immediately after blood sampling. The cows were divided into three groups according to BHBA concentration: nonketotic $(<1.2 \mathrm{mmol} / \mathrm{L})$, subclinically ketotic $(1.2 \leq \mathrm{BHBA} \leq$ $2.9 \mathrm{mmol} / \mathrm{L})$, clinically ketotic $(\geq 3.0 \mathrm{mmol} / \mathrm{L})(35,36)$. The clinically ketotic cows used in this study decreased milk yield (MY) over $10 \%$, compared to the previous day for the last 2 days before beginning treatment. Cows with clinical ketosis were randomly assigned to one of three treatment groups (6 cases per group): (1) levocarnitine $(\mathrm{C}+\mathrm{G})$ (Carnitine Plus Inj., Unibiotech Co., Ltd., Anyang, Korea), (2) vitamin B complex and E with selenium (VBES+G) (Vitacom Inj., Handong Co., Ltd., Seoul, Korea, and Selevit, Fatro, Ozzano dell'Emilia, Italy), and (3) levocanitine and vitamin B complex and E with selenium $(\mathrm{C}+\mathrm{VBES}+\mathrm{G})$. Glycerin was administered orally to all groups consecutively for 4 days (500 ml, Eloglyn 995D, LG Household \& Health Care LTD., Seoul, Korea), based on a previous study (37). Levocarnitine was administered intravenously $10 \mathrm{~g}$ at the first treatment and $3 \mathrm{~g}$ for 3 days thereafter. Regarding vitamin B complex, thiamine hydrochloride $250 \mathrm{mg}$, riboflavin sodium phosphate $10 \mathrm{mg}$, pyridoxine hydrochloride $10 \mathrm{mg}$, and nicotinamide $250 \mathrm{mg}$ were injected intravenously for 4 days, whereas cyanocobalamin $1 \mathrm{mg}$ was administered subcutaneously. Vitamin E ( $\alpha$-tocopherol, $700 \mathrm{mg}$ ) and selenium $(1.5 \mathrm{mg}$ ) was administered subcutaneously for 4 days. The treatments were administered, following the administration method and dosage of each medicine. Blood sampling was conducted 1 day (day 4) and 3 days (day 6) after the final treatment in the morning (Figure 1).

\section{Blood Analysis and Data Collection}

Serum was harvested by centrifuging SST tubes at 3,000 rpm $(2,600 \mathrm{~g})$ for $10 \mathrm{~min}$. The serum was frozen and stored at $-70^{\circ} \mathrm{C}$ pending analysis. The serum biochemical analysis was performed using a biochemistry automatic analyzer (Hitachi 7180, Hitachi Ltd., Tokyo, Japan). The levels of glucose, total protein (TP), albumin, NEFA, TG, alanine transaminase (ALT), aspartate transaminase (AST), and gamma-glutamyl transferase (GGT) were measured by commercial enzyme assay kits made by Wako (Fujifilm Wako Pure Chemical Ltd., Osaka, Japan). Globulin levels were calculated as the differences between TP and albumin values. Total bilirubin (TB) was analyzed immediately after centrifugation by using Catalyst ${ }^{\mathrm{TM}}$ Dx chemistry analyzer. MY was obtained through a milking
TABLE 2 | Descriptive statistics for dairy cows by each treatment included in the study.

\begin{tabular}{lcccc}
\hline Variable & $\mathbf{C}+\mathbf{G}$ & $\mathbf{V B E S}+\mathbf{G}$ & $\mathbf{C}+$ VBES + G & $\boldsymbol{p}$-value \\
\hline Number & 6 & 6 & 6 & \\
Cow parity & $2.33 \pm 1.21$ & $3.00 \pm 1.55$ & $3.00 \pm 2.10$ & 0.729 \\
Age at calving & $4.77 \pm 1.31$ & $6.48 \pm 2.12$ & $6.62 \pm 3.16$ & 0.333 \\
$\begin{array}{l}\text { Body condition } \\
\text { score }\end{array}$ & $3.17 \pm 0.20$ & $3.04 \pm 0.33$ & $3.15 \pm 0.45$ & 0.790 \\
$\begin{array}{l}\text { Incidence day of } \\
\text { clinical ketosis }\end{array}$ & $16.50 \pm 4.14$ & $10.50 \pm 4.14$ & $9.50 \pm 4.42$ & 0.024 \\
\end{tabular}

Data are presented as the mean \pm standard deviation. $C+G=$ levocarnitine and glycerin, $V B E S+G=$ vitamin $B$ complex, vitamin $E$ with selenium, and glycerin, $C+V B E S+G=$ levocarnitine, vitamin B complex, vitamin $E$ with selenium, and glycerin.

metering system (Alpro system, DeLaval, Tumba, Sweden). Change of MY was obtained by subtracting milk yield on the onset of ketosis from milk yield on specific date, and dividing that by milk yield on the onset, and then multiplying that with $100\left[\left(\mathrm{MY}_{(\text {Dayx })}-\mathrm{MY}_{(\text {Day0 })}\right) / \mathrm{MY}_{(\text {Day0 })} * 100\right]$.

\section{Statistical Analyses}

Statistical analyses were performed using SPSS software (version 26.0; IBM Corp., Armonk, NY, USA). Repeated-measures analysis of variance was used to assess the levels of BHBA, glucose, TP, albumin, NEFA, TG, ALT, AST, GGT, and milk yield on days 0,4 , and 6 . Time and treatment were the fixed effects, while cow nested within the group was the random effect. Group and time were the main effects, and group-by-time was the interaction effect. When the effects were significant $(p<0.05)$, the analysis of variance with post hoc Bonferroni correction was used to evaluate the difference by time or group. Paired $t$-test was used to compare within-group categorical variable changes by time. All data are expressed as the mean \pm standard deviation (SD). Significance level was interpreted based on the $P$-value; 0.01 $\leq p<0.05$ significant, $0.001 \leq p<0.01$ very significant, and $p<$ 0.001 extremely significant.

\section{RESULTS}

\section{Descriptive Statistics for Dairy Cows by Each Treatment}

In total, 18 cases of Holstein Friesian cows with clinical ketosis were analyzed according to the treatment type. The levocarnitine $(\mathrm{C}+\mathrm{G})$ group calved less and was younger than the other groups. The average incidence days of clinical ketosis were the highest in the $\mathrm{C}+\mathrm{G}$ group. The levocarnitine and vitamin $\mathrm{B}$ complex and vitamin $\mathrm{E}$ with Selenium $(\mathrm{C}+\mathrm{VBES}+\mathrm{G})$ group had the oldest cows and highest parity, and they suffered from clinical ketosis earlier than cows from any other group (Table 2).

\section{Changes in $\beta$-hydroxybutyrate and Glucose Concentration by the Treatments}

The effects of 3 kinds of treatments on BHBA and glucose of Holstein Friesian cows with clinical ketosis were investigated. The tests of between-subjects effect were very significant in 


\section{Day after onset of clinical ketosis}

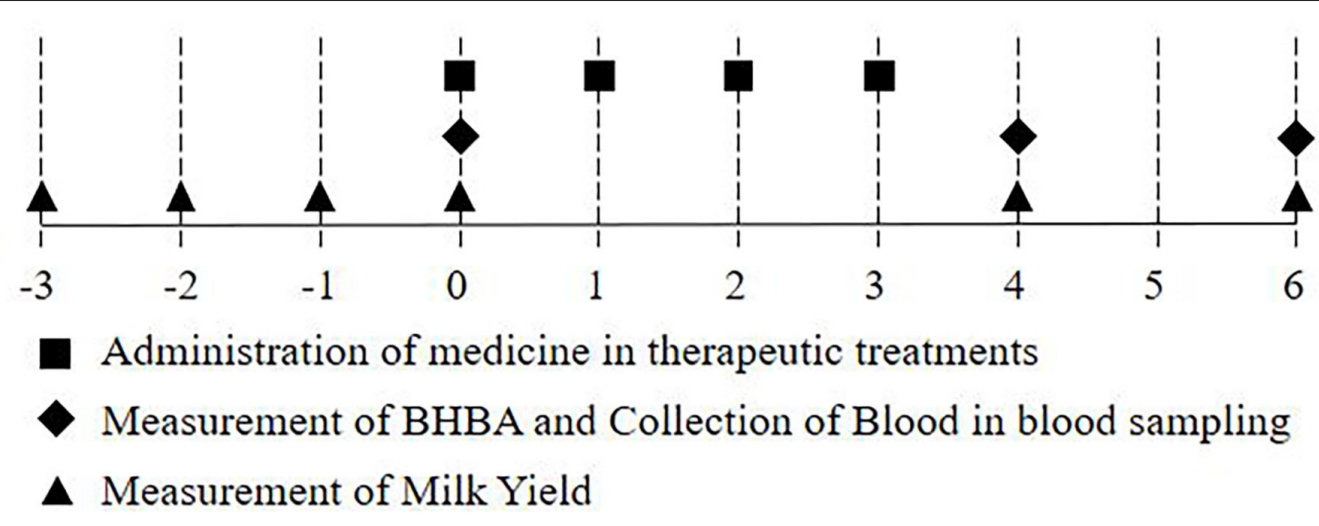

FIGURE 1 | Scheme of this study: Administration of medicine in therapeutic treatments, collection of blood in blood sampling, and measurement of $\beta$-hydroxybutyrate $(\mathrm{BHBA})$ and milk yield.

glucose $(p=0.006)$, but not significant in BHBA ( $p=0.081)$. In the tests of Within-Subjects Contrasts, the main effects of time were extremely significant in both BHBA and glucose concentrations $(p<0.001)$. The interaction effect of groupby-time was extremely significant in BHBA $(p<0.001)$, but not significant in glucose $(p=0.069)$. The difference of BHBA between groups was not significant on day 4 (the day after the last treatment), but on day 6 (3 days after the last treatment). Half of $\mathrm{C}+\mathrm{G}$ group failed to overcome clinical ketosis on both day 4 and 6 . VBES $+\mathrm{G}$ was ameliorated on day 4 , but BHBA of this group increased on day 6 and a third of the group returned to clinical ketosis on day 6 . All cases of $\mathrm{C}+\mathrm{VBES}+\mathrm{G}$ group overcame clinical ketosis on both day 4 and day 6 . The decreased amount of BHBA was the biggest among groups. Most cases of $\mathrm{C}+\mathrm{VBES}+\mathrm{G}$ group revived to non-ketosis on day 6 (83.3\%), while one case slightly failed to overcome subclinical ketosis $(1.2 \mathrm{mmol} / \mathrm{L})$. C + VBES + G group significantly improved glucose concentration after the treatment, while the other groups made little improvements on both day 4 and 6 (Tables 3, 4 and Figure 2).

\section{Changes in Daily Milk Yield by Treatments}

Improvement in MY was measured depending on the type of treatment. MY was not statistically significant. All groups showed increased daily MY on day 4 compared with the average MY during the last 3 days before ketosis onset and that on day 0 . The $\mathrm{C}+\mathrm{VBES}+\mathrm{G}$ group showed a greater increase in MY compared with the other groups from day 0 to 4 . The $\mathrm{C}+\mathrm{VBES}+\mathrm{G}$ group showed an increase in MY from days 4 to 6 . The $\mathrm{C}+\mathrm{G}$ and VBES $+\mathrm{G}$ groups showed decreased MY on day 6 compared with that on day 4. Although the gap in MY among the groups on day 6 was small, the change in MY in the $\mathrm{C}+\mathrm{VBES}+\mathrm{G}$ group was the largest (Figure 3).

\section{Changes in Serum Biochemical Values by Treatments}

The changes in the serum biochemical parameters were assessed. Most of serum biochemical values were not statistically significant. However, in the within-subjects contrast tests, the
TABLE 3 | Interaction effect of time and group on BHBA and glucose concentration by repeated measures ANOVA.

\begin{tabular}{|c|c|c|c|c|c|}
\hline $\begin{array}{l}\text { Source of } \\
\text { variation }\end{array}$ & $\begin{array}{l}\text { Sum of } \\
\text { squares }\end{array}$ & $\begin{array}{l}\text { Degrees of } \\
\text { freedom }\end{array}$ & $\begin{array}{c}\text { Mean } \\
\text { squares }\end{array}$ & $\boldsymbol{F}$ & $p$-value \\
\hline \multicolumn{6}{|l|}{ BHBA } \\
\hline Time & 30.535 & 2 & 15.267 & 34.464 & $<0.001$ \\
\hline Time*Group & 14.775 & 4 & 3.694 & 8.338 & $<0.001$ \\
\hline Error & 13.290 & 30 & 0.443 & & \\
\hline Group & 7.194 & 2 & 3.597 & 2.989 & 0.081 \\
\hline Error & 18.052 & 15 & 1.203 & & \\
\hline \multicolumn{6}{|l|}{ Glucose } \\
\hline Time & $1,408.037$ & 2 & 704.019 & 14.759 & $<0.001$ \\
\hline Time*Group & 463.630 & 4 & 115.907 & 2.430 & 0.069 \\
\hline Error & 1,431.000 & 30 & 47.700 & & \\
\hline Group & $1,439.148$ & 2 & 719.574 & 7.434 & 0.006 \\
\hline Error & $1,451.833$ & 15 & 96.789 & & \\
\hline
\end{tabular}

TABLE 4 | Percentage of ketotic types on pre-treatment day (Day 0), and on 1 day (Day 4) and 3 days (Day 6) after the last treatment day.

\begin{tabular}{|c|c|c|c|c|c|c|c|c|c|}
\hline & \multicolumn{3}{|c|}{$C+G(n=6)$} & \multicolumn{3}{|c|}{ VBES + G $(n=6)$} & \multicolumn{3}{|c|}{$C+$ VBES + G $(n=6)$} \\
\hline & NK & SCK & CK & NK & SCK & CK & NK & SCK & CK \\
\hline Day 0 & & & 100 & & & 100 & & & 100 \\
\hline Day 4 & & 50 & 50 & & 100 & & 50 & 50 & \\
\hline Day 6 & 16.7 & 33.3 & 50 & & 66.7 & 33.3 & 83.3 & 16.7 & \\
\hline
\end{tabular}

NK, non-ketosis; SCK, subclinical ketosis; CK, clinical ketosis. $C+G$, levocarnitine and glycerin; VBES+G, vitamin B complex, vitamin E with selenium, and glycerin; $C+V B E S+G$, levocarnitine, vitamin B complex, vitamin E with selenium, and glycerin.

main effects of time were very significant in both TP and globulin concentrations $(p \leq 0.001)$. The interaction effect of group-by-time was significant in globulin $(p<0.05)$, but there was not significant difference of globulin between groups. Both $\mathrm{VBES}+\mathrm{G}$ and $\mathrm{C}+\mathrm{VBES}+\mathrm{G}$ groups substantially increased the albumin concentration $(0.12-0.18 \mathrm{~g} / \mathrm{dL})$ on day 6 , compared 

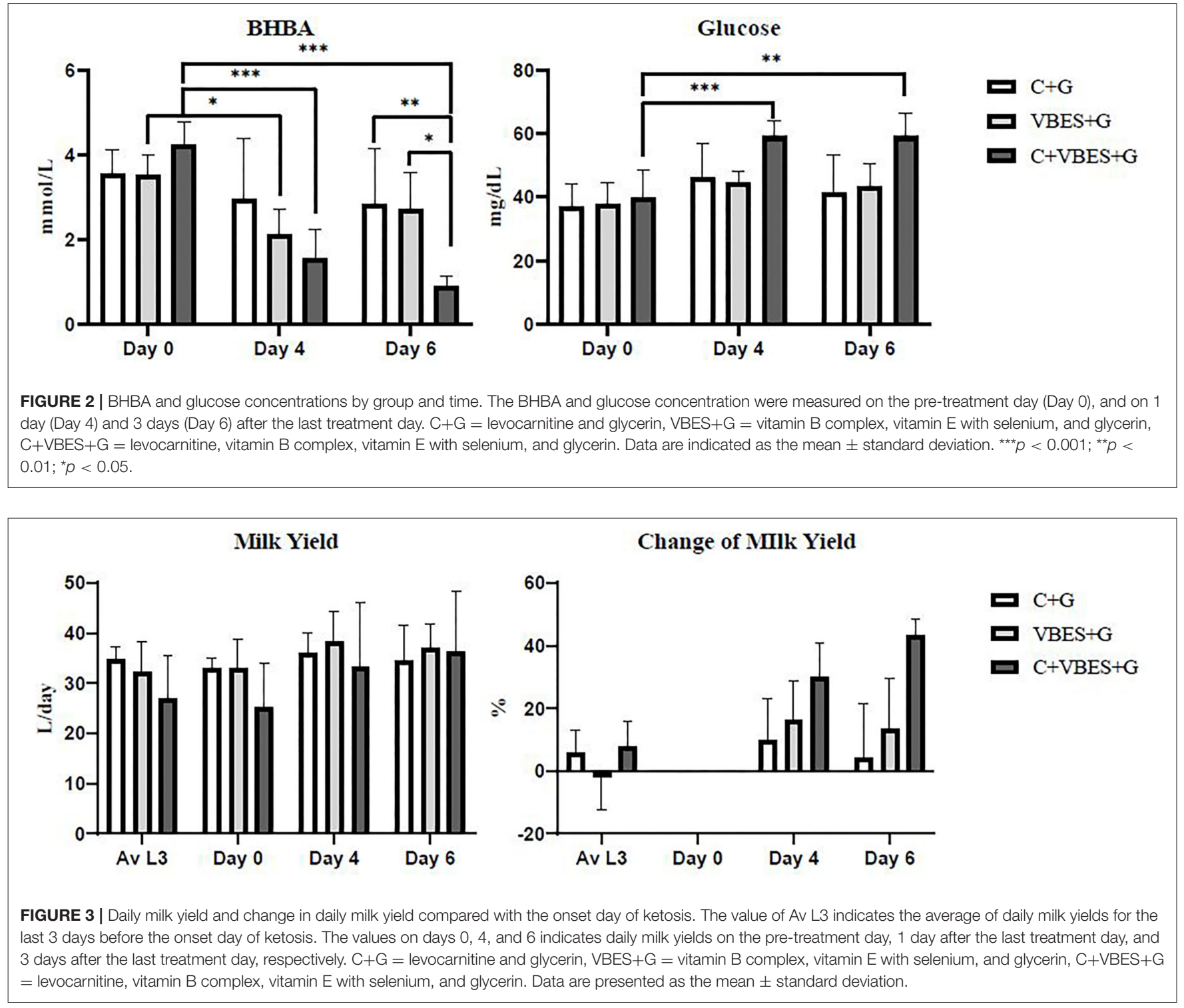

with that in day 0 . Globulin concentration significantly increased on day 6 , compared with that on day 0 in both the VBES+G and $\mathrm{C}+\mathrm{VBES}+\mathrm{G}$ groups (0.43-0.7 g/dL). However, negligible changes by time in albumin $(<0.05 \mathrm{~g} / \mathrm{dL})$ and globulin $(<$ $0.22 \mathrm{~g} / \mathrm{dL}$ ) levels were observed in the $\mathrm{C}+\mathrm{G}$ group. The $\mathrm{C}+\mathrm{VBES}+\mathrm{G}$ group showed a considerable decrease $(0.10 \mathrm{mEq} / \mathrm{L}$, day $4 ; 0.47 \mathrm{mEq} / \mathrm{L}$, day 6 ) in NEFA, compared with that on day 0 . Both $\mathrm{C}+\mathrm{G}$ and $\mathrm{VBES}+\mathrm{G}$ groups showed considerably decreased NEFA on day 4, but showed increased NEFA on day 6. All groups showed improvement in the TG and TB levels. The TG level improved significantly in both VBEST+G and $\mathrm{C}+\mathrm{VBES}+\mathrm{G}$ groups between day 0 and day $6(p<$ $0.05)$. The $\mathrm{C}+\mathrm{VBES}+\mathrm{G}$ group showed the greatest improvement in the TG and TB. No significant changes in ALT, AST, and GGT levels were observed among groups (Table 5 and Figure 4).

\section{DISCUSSION}

This study was conducted to evaluate the effects of treatment with levocarnitine $(\mathrm{C}+\mathrm{G})$, vitamin $\mathrm{B}$ complex, and $\mathrm{E}$ with selenium $(\mathrm{VBES}+\mathrm{G})$, and the combination of levocarnitine and vitamin $B$ complex and $E$ with selenium $(C+V B E S+G)$, each in combination with glycerin, on the resolution of clinical ketosis during the postpartum transition period, based on blood BHBA, milk production, and serum biochemical parameters. The effect of increasing fatty acid influx into the liver, stimulating metabolism with reducing oxidative stress, and the synergy of both was examined in cows with clinical ketosis, which were fed a precursor for glucose synthesis. The cows treated with $\mathrm{C}+\mathrm{VBES}+\mathrm{G}$ tended to demonstrate an improvement in clinical ketosis along with improvements in BHBA, glucose, MY, serum proteins, NEFA, TG, and TB compared with those in cows in 
TABLE 5 | Interaction effect of time and group on total protein, albumin, globulin, and triglyceride concentration by repeated measures ANOVA.

\begin{tabular}{|c|c|c|c|c|c|}
\hline $\begin{array}{l}\text { Source of } \\
\text { variation }\end{array}$ & $\begin{array}{l}\text { Sum of } \\
\text { squares }\end{array}$ & $\begin{array}{l}\text { Degrees of } \\
\text { freedom }\end{array}$ & $\begin{array}{c}\text { Mean } \\
\text { squares }\end{array}$ & $\boldsymbol{F}$ & $p$-value \\
\hline \multicolumn{6}{|c|}{ Total protein } \\
\hline Time & 2.434 & 2 & 1.217 & 8.222 & 0.001 \\
\hline Time*Group & 1.144 & 4 & 0.286 & 1.933 & 0.131 \\
\hline Error & 4.441 & 30 & 0.148 & & \\
\hline Group & 0.568 & 2 & 0.284 & 0.140 & 0.870 \\
\hline Error & 30.341 & 15 & 2.023 & & \\
\hline \multicolumn{6}{|l|}{ Albumin } \\
\hline Time & 0.105 & 2 & 0.052 & 1.260 & 0.298 \\
\hline Time*Group & 0.114 & 4 & 0.029 & 0.686 & 0.607 \\
\hline Error & 1.248 & 30 & 0.042 & & \\
\hline Group & 0.005 & 2 & 0.002 & 0.004 & 0.996 \\
\hline Error & 9.921 & 15 & 0.661 & & \\
\hline \multicolumn{6}{|l|}{ Globulin } \\
\hline Time & 1.736 & 2 & 0.868 & 19.513 & $<0.001$ \\
\hline Time*Group & 0.596 & 4 & 0.149 & 3.351 & 0.022 \\
\hline Error & 1.334 & 30 & 0.044 & & \\
\hline Group & 0.494 & 2 & 0.247 & 0.146 & 0.865 \\
\hline Error & 25.359 & 15 & 1.691 & & \\
\hline \multicolumn{6}{|l|}{ Triglyceride } \\
\hline Time & 18.815 & 2 & 9.407 & 6.019 & 0.006 \\
\hline Time*Group & 4.296 & 4 & 1.074 & 0.687 & 0.606 \\
\hline Error & 46.889 & 30 & 1.563 & & \\
\hline Group & 14.704 & 2 & 7.352 & 1.738 & 0.209 \\
\hline Error & 63.444 & 15 & 4.230 & & \\
\hline
\end{tabular}

the other groups. This could help treat cows with ketosis and establish suitable prevention strategies.

Daily MY is speculated to be associated with the alleviation of clinical ketosis, especially serum glucose concentration. The $\mathrm{C}+\mathrm{VBES}+\mathrm{G}$ group showed the greatest increase in the amount of milk, improvements in the BHBA and serum glucose concentration. Both $\mathrm{C}+\mathrm{G}$ and $\mathrm{VBES}+\mathrm{G}$ increased $\mathrm{MY}$ and improved serum glucose concentration on day 4 , compared with that on the onset day (day 0) of ketosis. However, both $\mathrm{C}+\mathrm{G}$ and $\mathrm{VBES}+\mathrm{G}$ decreased MY and glucose concentration on day 6 , compared with that on day 4 . This corresponds to the findings of previous studies, which showed that cows that overcame ketosis produced more milk than untreated cows $(4,12,13,38)$.

NEFA tended to be associated with the concentrations of $\mathrm{BHBA}$ and serum glucose, to greater or less degrees. The concentrations of $\mathrm{BHBA}$ and serum glucose improved as the NEFA concentration decreased. Stabilization of glucose concentration moderates NEFA mobilization, which reduces BHBA $(1,39)$. Here, the $C+V B E S+G$ group maintained the improvement in the BHBA, glucose, and NEFA concentrations without the treatment (from day 4 to 6), even though the other groups did not show an improvement in all of these parameters. This difference may derive from serum glucose concentration on day 4. In $\mathrm{C}+\mathrm{VBES}+\mathrm{G}$, a high glucose concentration on day 4 might contribute to a decrease in NEFA mobilization and BHBA concentration. In contrast, $\mathrm{C}+\mathrm{G}$ and $\mathrm{VBES}+\mathrm{G}$ with low serum glucose concentration might fail to decrease NEFA mobilization and BHBA concentration.
Glycerin reduces NEFA and BHBA $(22,40,41)$. In the present study, all groups showed decreased NEFA and BHBA levels. However, glycerin alone may be insufficient to overcome clinical ketosis. Three cases in the $\mathrm{C}+\mathrm{G}$ group still showed clinical ketosis and two cases in the VBES $+\mathrm{G}$ group showed exacerbation to clinical ketosis during the time of no treatment. Glycerin may contribute to increased glucose concentrations, which was observed in all the groups. The rumen completely ferments glycerin to volatile fatty acids such as propionate and butyrate $(42,43)$. Propionate is converted to glucose via gluconeogenesis in the liver (44). Hepatic gluconeogenesis is responsible for over $90 \%$ of glucose production (45). Increased propionate is linked with increased glucose production.

Levocarnitine is involved in metabolic functions, including the transport of long chain free fatty acids from the cytosol to the mitochondrial matrix in the outer mitochondrial membrane. These fatty acids undergo $\beta$-oxidation to produce energy $(46,47)$. Fatty acid $\beta$-oxidation results in high concentrations of BHBA in the blood (48). Dietary levocarnitine supplementation increases the capacity to oxidize NEFA, which decreases fat accumulation in the liver (49). Improved fat accumulation and glucose output in the liver by carnitine supplementation ameliorate glucose status during early lactation (48). Furthermore, Owen et al. reported that the liver produces more glucose with carnitine supplementation, which increases metabolite flux through pyruvate carboxylase (50). In the present study, using levocarnitine alone with glycerin did not significantly improve the BHBA and glucose concentrations, and may thus be insufficient to improve ketosis. However, when the $\mathrm{C}+\mathrm{VBES}+\mathrm{G}$ group is compared with the $\mathrm{VBES}+\mathrm{G}$ group, levocarnitine must considerably contribute to improvements in the BHBA and glucose concentrations and the persistence of its effect. The results indicate that fatty acids, which are transported into the mitochondrial matrix by levocarnitine, must be metabolized to ameliorate ketosis, and that levocarnitine substantially contributes to the resolution of ketosis once fatty acids can be metabolized properly in the liver. Holstein cows with clinical ketosis during the transition period may need materials to improve the influx of fatty acids into the mitochondria of the hepatic cell, as well as substances to improve the metabolism of hepatic cells.

Vitamin B complex and E with selenium may improve ketosis by supplementing the deficiencies in dairy cows with ketosis for efficient metabolism. Cows with ketosis show excessive lipid accumulation in the liver, which damages mitochondrial function, metabolism, and cellular signal transduction, and causes severe oxidative stress and apoptosis by weakening endogenous antioxidant defenses $(10,51,52)$. The vitamin B complex plays essential roles in carbohydrate, protein, and fat metabolism, by serving as enzyme cofactors. Thiamine, riboflavin, and niacin contribute to converting pyruvate to acetyl-CoA and producing energy through the tricarboxylic acid (TCA) cycle (30,53-57). Metabolic enzymes that require riboflavin also include glycerol-3-phosphate dehydrogenase, which is involved in glycerol phosphate shuttle and triglyceride synthesis in the liver (58). Nicotinamide adenine dinucleotide (NAD), which is converted from niacin, serves as a cofactor for 


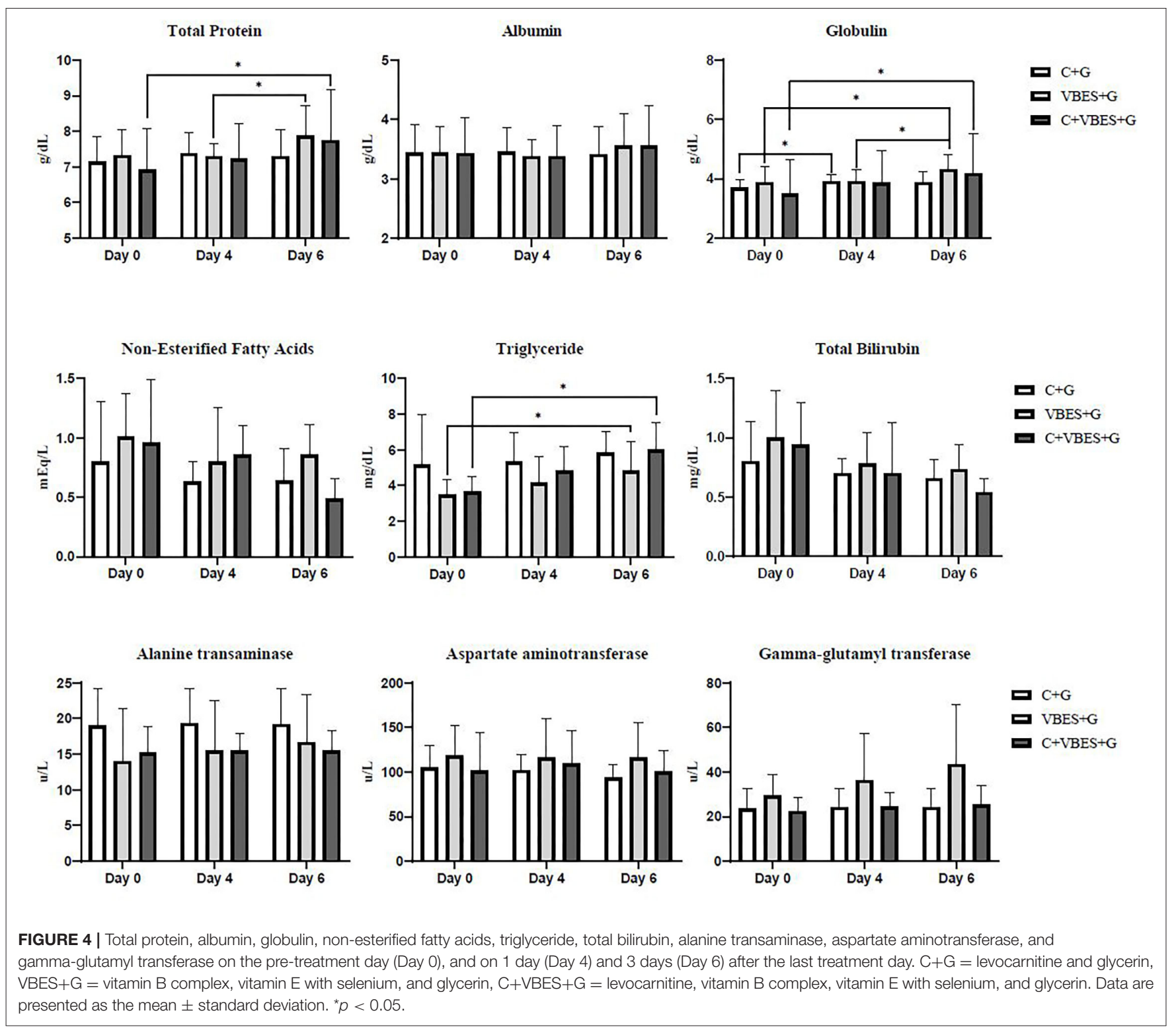

$\beta$-hydroxybutyrate dehydrogenase to degrade ketone bodies (59). Pyridoxal phosphate, the biologically active form of pyridoxine, is involved in catalyzing transamination and catabolizing glycogen to glucose (60). Cyanocobalamin participates in the degradation of amino acids such as valine, isoleucine, methionine, and threonine, odd-chain fatty acids, and cholesterol to produce succinyl-CoA, an intermediate product of the TCA cycle (61). Vitamin $\mathrm{E}$ is low in cows with hepatic failure and functions as an antioxidant by preventing oxidative damage to hepatic tissue $(62,63)$. Selenoproteins, which selenium plays a major component of, function as essential enzymes to reduce oxidation and maintain homeostasis (64). Plasma selenium concentration is positively associated with the capacity of antioxidation, and the administration of selenium induces antioxidant enzymes in subclinical ketosis $(10,65)$. The accumulative effect of vitamin $\mathrm{B}$ complex and $\mathrm{E}$ with selenium resulted in recovery from clinical ketosis immediately after treatment, as well as improvement in the serum protein status. Malnutrition and liver atrophy result in insufficient protein synthesis, which is associated with hypoalbuminemia and hypoglobulinemia (66). Increased albumin, globulin, and TG may be linked with the improvement in liver function. This effect extended after 2 days without treatment. However, treatment without levocarnitine was less effective than that with levocarnitine in terms of concentrations of BHBA and glucose and improvement in milk yield. This is due to the role of levocarnitine. These results indicate that overcoming ketosis requires increased metabolism of fatty acids and BHBA through the TCA cycle and reduced oxidative stress, as well as reduced fatty acid concentrations through transportation from the cytosol to the mitochondria in the liver.

We made efforts to have cows of similarity in parity, age at calving, and incidence day of clinical ketosis in all groups, but we could not because these ketotic cases were natural, not 
induced. The $\mathrm{C}+\mathrm{VBES}+\mathrm{G}$ group, which had higher number of parity and age, showed better results. Based on which cows with more parity and older age are vulnerable to ketosis, $\mathrm{C}+\mathrm{VBES}+\mathrm{G}$ may be more effective than the other treatments. The influence of incidence day of clinical ketosis on the results are unclear. However, in this study, all cases were confined in the postpartum transition period (for 21 days from the calving date) as mentioned in the materials and methods. The influence of incidence day of clinical ketosis might be limited.

To our knowledge, this is the first study indicating that clinical ketosis might be treated with levocarnitine and vitamin B complex and E with selenium along with oral administration of glycerin. Our findings suggest a new treatment in which dairy Holstein cows may overcome clinical ketosis using this combination. However, further studies are needed to confirm and clarify their effects on various cows. The administration method and dosage of levocarnitine, vitamin B complex, vitamin E, selenium and glycerin should be studied further because we just followed the instructions of pharmaceutical companies and a previous study (31).

In conclusion, three types of treatment using levocarnitine and vitamin $\mathrm{B}$ complex and $\mathrm{E}$ with selenium, in combination of glycerin, were applied to cows with clinical ketosis. Using all these treatments in combination resulted in improvements in clinical ketosis compared with that achieved with each treatment. The synergistic effect of glycerin, levocarnitine, and vitamin $\mathrm{B}$ complex and $\mathrm{E}$ with selenium is possible to help cows to overcome clinical ketosis with improved BHBA, glucose, MY, serum protein, and NEFA. In addition, this effect might persist after stopping the treatment. Our study thus suggests a new treatment strategy for ketosis. Further studies are required to elucidate the effect of these treatments for application to various cows.

\section{REFERENCES}

1. Herdt TH. Ruminant adaptation to negative energy balance: influences on the etiology of ketosis and fatty liver. Vet Clin: Food Animal Pract. (2000) 16:215-30. doi: 10.1016/S0749-0720(15) 30102-X

2. Drackley JK. Biology of dairy cows during the transition period: The final frontier? J Dairy Sci. (1999) 82:225973. doi: $10.3168 /$ jds.S0022-0302(99)75474-3

3. Gordon JL, LeBlanc SJ, Duffield TF. Ketosis treatment in lactating dairy cattle. The veterinary clinics of North America. Food Animal Prac. (2013) 29:433-45. doi: 10.1016/j.cvfa.2013.03.001

4. Evaluation of results from a therapeutic trial on bovine ketosis. In: Robertso JM, editor. Journal of the American Veterinary Medical Association. $1931 \mathrm{~N}$ MEACHAM RD SUITE 100, SCHAUMBURG, IL 60173-4360: AMER Veterinary Medical Association. p. 1620 (1966).

5. Ruegsegger G, Schultz L. Use of a combination of propylene glycol and niacin for subclinical ketosis. J Dairy Sci. (1986) 69:1411-5. doi: 10.3168/jds.S0022-0302(86)80548-3

6. Sakai T, Hayakawa T, Hamakawa M, Ogura K, Kubo S. Therapeutic effects of simultaneous use of glucose and insulin in ketotic dairy cows. J Dairy Sci. (1993) 76:109-14. doi: 10.3168/jds.S0022-0302(93) 77329-4

\section{DATA AVAILABILITY STATEMENT}

The raw data supporting the conclusions of this article will be made available by the authors, without undue reservation.

\section{ETHICS STATEMENT}

The animal study was reviewed and approved by the Institutional Animal Care and Use Committee (IACUC) at the National Institute of Animal Science, Republic of Korea (approved number: NIAS-2020127).

\section{AUTHOR CONTRIBUTIONS}

SH: conceptualization, methodology, software, validation, investigation, data curation, writing original draft preparation, visualization, and project administration. SK and $\mathrm{MH}$ : project administration and funding acquisition. JL, HC, and DK: methodology. JP: conceptualization, validation, data curation, writing review and editing, and supervision. All authors contributed to the article and approved the submitted version.

\section{FUNDING}

This research was funded by The improvement of animal diseases control in National Institute of Animal Science (Project No. PJ01567603) project at National Institute of Animal Science, Rural Development Administration, Republic of Korea.

\section{ACKNOWLEDGMENTS}

The authors would like to express our deepest gratitude to Choongkyeong Kim, Youngso Hong, Jaegi Kim, and Hyunhoon Sung for their technical support.

7. Shpigel N, Chen R, Avidar Y, Bogin E. Use of corticosteroids alone or combined with glucose to treat ketosis in dairy cows. J Am Vet Med Assoc. (1996) 208:1702.

8. Lohr B, Brunner B, Janowitz H, Hummel M, Seeger T, Weber I, et al. Efficacy of catosal (R) for the treatment of ketosis in cows with left abomasal displacement. Tierärztliche Umschau. (2006) 61:187-90.

9. Seifi HA, LeBlanc S, Vernooy E, Leslie K, Duffield T. Effect of isoflupredone acetate with or without insulin on energy metabolism, reproduction, milk production, and health in dairy cows in early lactation. J Dairy Sci. (2007) 90:4181-91. doi: 10.3168/jds.2006-897

10. Sahoo S, Patra R, Behera P, Swarup D. Oxidative stress indices in the erythrocytes from lactating cows after treatment for subclinical ketosis with antioxidant incorporated in the therapeutic regime. Vet Res Commun. (2009) 33:281-90. doi: 10.1007/s11259-008-9176-1

11. Carrier J, Godden S, Fetrow J, Rapnicki P, editors. Clinical trial of early ketosis detection and therapy in fresh cows. In: Proceedings of the Annual Conference of the American Association of Bovine Practitioners. Saint Louis, Missouri, USA (2011).

12. McArt J, Nydam D, Ospina P, Oetzel G, A field trial on the effect of propylene glycol on milk yield and resolution of ketosis in fresh cows diagnosed with subclinical ketosis. J Dairy Sci. (2011) 94:6011-20. doi: 10.3168/jds.2011-4463

13. McArt J, Nydam D, Oetzel G, A. field trial on the effect of propylene glycol on displaced abomasum, removal from herd, and reproduction in 
fresh cows diagnosed with subclinical ketosis. J Dairy Sci. (2012) 95:250512. doi: $10.3168 /$ jds.2011-4908

14. Piantoni P, Allen M. Evaluation of propylene glycol and glycerol infusions as treatments for ketosis in dairy cows. J Dairy Sci. (2015) 98:542939. doi: 10.3168/jds.2015-9476

15. Jeong J-K, Choi I-S, Moon S-H, Lee S-C, Kang H-G, Jung Y-H, et al. Effect of two treatment protocols for ketosis on the resolution, postpartum health, milk yield, and reproductive outcomes of dairy cows. Theriogenology. (2018) 106:53-9. doi: 10.1016/j.theriogenology.2017.09.030

16. Sakai T, Hamakawa M, Kubo S. Glucose and xylitol tolerance tests for ketotic and healthy dairy cows. J Dairy Sci. (1996) 79:372-7. doi: 10.3168/jds.S0022-0302(96)76374-9

17. Wagner SA, Schimek DE. Evaluation of the effect of bolus administration of $50 \%$ dextrose solution on measures of electrolyte and energy balance in postpartum dairy cows. Am Vet Med Assoc. (2010) 71:1074-1080. doi: 10.2460/ajvr.71.9.1074

18. Hippen AR, DeFrain JM, Linke PL, editors. Glycerol and other energy sources for metabolism and production of transition dairy cows. In: Florida Ruminant Nutrition Symposium (2008).

19. Kupczyński R, Szumny A, Wujcikowska K, Pachura N. Metabolism, ketosis treatment and milk production after using glycerol in dairy cows: a review. Animals. (2020) 10:1379. doi: 10.3390/ani10081379

20. Zhang F, Nan X, Wang H, Zhao Y, Guo Y, Xiong B. Effects of propylene glycol on negative energy balance of postpartum dairy cows. Animals. (2020) 10:1526. doi: 10.3390/ani10091526

21. Goff JP, Horst RL. Oral glycerol as a gluconeogenic precursor in the treatment of ketosis and fatty liver. Acta Vet Scand. (2003) 44:12. doi: 10.1186/1751-0147-44-S1-P40

22. Osman M, Allen P, Mehyar N, Bobe G, Coetzee J, Koehler K, et al. Acute metabolic responses of postpartal dairy cows to subcutaneous glucagon injections, oral glycerol, or both. J Dairy Sci. (2008) 91:331122. doi: $10.3168 /$ jds.2008-0997

23. Citil M, Karapehlivan M, Erdogan HM, Yucayurt R, Atakisi E, Atakisi O. Effect of orally administered L-carnitine on selected biochemical indicators of lactating Tuj-ewes. Small Ruminant Res. (2009) 81:1747. doi: 10.1016/j.smallrumres.2008.12.001

24. Pirestani A, Rokh S, Tabatabaei S, Ghalamkari G, Alibabaei Z. Effect of Lcarnitin supplement in diet transitional cows on reproduction indices and milk parameters. Vet J Islam Azad Univ-Tabriz Branch. (2009) 3:205-8.

25. Shaver R, Bal M. Effect of dietary thiamin supplementation on milk production by dairy cows. J Dairy Sci. (2000) 83:233540. doi: 10.3168/jds.S0022-0302(00)75121-6

26. Fronk T, Schultz L. Oral nicotinic acid as a treatment for ketosis. J Dairy Sci. (1979) 62:1804-7. doi: 10.3168/jds.S0022-0302(79)83501-8

27. Riddell D, Bartley E, Dayton A. Effect of nicotinic acid on microbial protein synthesis in vitro and on dairy cattle growth and milk production. J Dairy Sci. (1981) 64:782-91. doi: 10.3168/jds.S0022-0302(81)82648-3

28. Zimmerly $\mathrm{C}, \mathrm{Weiss} \mathrm{W}$. Effects of supplemental dietary biotin on performance of Holstein cows during early lactation. J Dairy Sci. (2001) 84:498506. doi: 10.3168/jds.S0022-0302(01)74500-6

29. Girard C, Matte J. Dietary supplements of folic acid during lactation: effects on the performance of dairy cows. J Dairy Sci. (1998) 81:14129. doi: 10.3168/jds.S0022-0302(98)75705-4

30. Janssen JJ, Grefte S, Keijer J, De Boer VC. Mito-nuclear communication by mitochondrial metabolites and its regulation by B-vitamins. Front Physiol. (2019) 10:78. doi: 10.3389/fphys.2019.00078

31. Burton GW, Traber MG. Vitamin E: antioxidant activity, biokinetics, and bioavailability. Annu Rev Nutr. (1990) 10:35782. doi: 10.1146/annurev.nu.10.070190.002041

32. Herdt TH, Smith JC. Blood-lipid and lactation-stage factors affecting serum vitamin $\mathrm{E}$ concentrations and vitamin $\mathrm{E}$ cholesterol ratios in dairy cattle. J Vet Diagn Invest. (1996) 8:228-32. doi: 10.1177/104063879600800213

33. Allison R, Laven R. Effect of vitamin E supplementation on the health and fertility of dairy cows: a review. Vet Rec. (2000) 147:703-8. doi: $10.1136 /$ vr.147.25.703

34. Mehdi Y, Dufrasne I. Selenium in cattle: a review. Molecules. (2016) 21:545. doi: 10.3390/molecules21040545
35. Mellado M, Dávila A, Gaytán L, Macías-Cruz U, Avendaño-Reyes L, García E. Risk factors for clinical ketosis and association with milk production and reproduction variables in dairy cows in a hot environment. Trop Anim Health Prod. (2018) 50:1611-6. doi: 10.1007/s11250-018-1602-y

36. Jeong J-K, Choi I-S, Moon S-H, Lee S-C, Kang H-G, Jung Y$\mathrm{H}$, et al. Risk factors for ketosis in dairy cows and associations with some blood metabolite concentrations. J Vet Clin. (2017) 34:255-60. doi: 10.17555/jvc.2017.08.34.4.255

37. Osman M, Mehyar N, Bobe G, Coetzee JF, Beitz DC. Acute Effects of Subcutaneous Injection of Glucagon and/or Oral Administration of Glycerol on Blood Metabolites and Hormones of Holstein Dairy Cows Affected with Fatty Liver Disease. Iowa State University Animal Industry Report (2006) 3. doi: 10.31274/ans_air-180814-834

38. Gordon J, LeBlanc S, Neuder L, Herdt T, Kelton D, Duffield T. Efficacy of a combination butaphosphan and cyanocobalamin product and insulin for ketosis treatment. J Dairy Sci. (2012) 95:177.

39. Adewuyi A, Gruys E, Van Eerdenburg F. Non esterified fatty acids (NEFA) in dairy cattle. Rev Vet Q. (2005) 27:11726. doi: 10.1080/01652176.2005.9695192

40. Johnson RB. The treatment of ketosis with glycerol and propylene glycol. Cornell Veterinarian. (1954) 44:6-21.

41. Fisher L, Erfle J, Lodge G, Sauer F. Effects of propylene glycol or glycerol supplementation of the diet of dairy cows on feed intake, milk yield and composition, and incidence of ketosis. Can J Anim Sci. (1973) 53:28996. doi: $10.4141 /$ cjas $73-045$

42. Rémond B, Souday E, Jouany J. In vitro and in vivo fermentation of glycerol by rumen microbes. Anim Feed Sci Technol. (1993) 41:12132. doi: 10.1016/0377-8401(93)90118-4

43. Silva LG, Torrecilhas JA, Ornaghi MG, Eiras CE, Prado RMd, Prado IN. Glycerin and essential oils in the diet of Nellore bulls finished in feedlot: animal performance and apparent digestibility. Acta Scientiarum Anim Sci. (2014) 36:177-84. doi: 10.4025/actascianimsci.v36i2.23089

44. Drackley JK, Overton TR, Douglas GN. Adaptations of glucose and long-chain fatty acid metabolism in liver of dairy cows during the periparturient period. J Dairy Sci. (2001) 84:E100-12. doi: 10.3168/jds.S0022-0302(01)70204-4

45. Kozloski GV. Bioquímica dos ruminantes. 3rd ed: Fundação de Apoio a Tecnologia e Ciencia-Editora UFSM (2017).

46. Greenwood R, Titgemeyer E, Stokka G, Drouillard J, Löest C. Effects of L-carnitine on nitrogen retention and blood metabolites of growing steers and performance of finishing steers. J Anim Sci. (2001) 79:25460. doi: $10.2527 / 2001.791254 \mathrm{x}$

47. Kaneko J, Harvey J, Bruss M. Clinical Biochemistry of Domestic Animals. 6th ed. Burlington, MA: National Academy Press. (2008).

48. Carlson D, McFadden J, D'Angelo A, Woodworth J, Drackley JK. Dietary L-carnitine affects periparturient nutrient metabolism and lactation in multiparous cows. J Dairy Sci. (2007) 90:3422-41. doi: 10.3168/jds.2006-811

49. Carlson D, McFadden J, Litherland N, Drackley JK. Dietary L-Carnitine Prevents Fat Accumulation in the Liver of Transition Dairy Cows. Feeding \& Nutrition. (2006).

50. Owen K, Jit H, Maxwell C, Nelssen J, Goodband R, Tokach M, et al. Dietary Lcarnitine suppresses mitochondrial branched-chain keto acid dehydrogenase activity and enhances protein accretion and carcass characteristics of swine. $J$ Anim Sci. (2001) 79:3104-12. doi: 10.2527/2001.79123104x

51. Naito Y, Suematsu M, Yoshikawa T. Free Radical Biology in Digestive Diseases. Basel: Karger Medical and Scientific Publishers (2010). doi: 10.1159/isbn.978-3-8055-9610-7

52. Du X, Chen L, Huang D, Peng Z, Zhao C, Zhang Y, et al. Elevated apoptosis in the liver of dairy cows with ketosis. Cell Physiol Biochem. (2017) 43:56878. doi: $10.1159 / 000480529$

53. Mayes PA, Bender DA. The citric acid cycle: the catabolism of acetyl-CoA. In: A LANGE Medical Book. p. 130 (2003).

54. Joosten V, van Berkel WJ. Flavoenzymes. Curr Opin Chem Biol. (2007) 11:195-202. doi: 10.1016/j.cbpa.2007.01.010

55. Subramanya SB, Subramanian VS, Said HM. Chronic alcohol consumption and intestinal thiamin absorption: effects on physiological and molecular parameters of the uptake process. Am J Physiol-Gastrointest Liver Physiol. (2010) 299:G23-31. doi: 10.1152/ajpgi.00132.2010 
56. Pan X, Nan X, Yang L, Jiang L, Xiong B. Thiamine status, metabolism and application in dairy cows: a review. Br J Nutr. (2018) 120:4919. doi: $10.1017 /$ S0007114518001666

57. Balasubramaniam S, Christodoulou J, Rahman S. Disorders of riboflavin metabolism. J Inherit Metab Dis. (2019) 42:608-19. doi: 10.1002/jimd. 12058

58. Lienhart W-D, Gudipati V, Macheroux P. The human flavoproteome. Arch Biochem Biophys. (2013) 535:150-62. doi: 10.1016/j.abb.2013. 02.015

59. Newman JC, Verdin E. $\beta$-hydroxybutyrate: much more than a metabolite. Diabetes Res Clin Pract. (2014) 106:173-81. doi: 10.1016/j.diabres.2014. 08.009

60. Liang J, Han Q, Tan Y, Ding H, Li J. Current advances on structure-function relationships of pyridoxal $5^{\prime}$-phosphate-dependent enzymes. Front Mol Biosci. (2019) 6:4. doi: 10.3389/fmolb.2019.00004

61. Takahashi-Iñiguez T, García-Hernandez E, Arreguín-Espinosa R, Flores ME. Role of vitamin B 12 on methylmalonyl-CoA mutase activity. J Zhejiang Univ Sci B. (2012) 13:423-37. doi: 10.1631/jzus.B1100329

62. Bouwstra R, Goselink R, Dobbelaar P, Nielen M, Newbold J, Van Werven $\mathrm{T}$. The relationship between oxidative damage and vitamin $\mathrm{E}$ concentration in blood, milk, and liver tissue from vitamin E supplemented and nonsupplemented periparturient heifers. J Dairy Sci. (2008) 91:97787. doi: 10.3168/jds.2007-0596

63. Mudron P, Rehage J, Qualmann K, Sallmann HP, Scholz H, A. study of lipid peroxidation and vitamin $\mathrm{E}$ in dairy cows with hepatic insufficiency. J Vet Med Series A. (1999) 46:219-24. doi: 10.1046/j.1439-0442.1999. 00206.x
64. Stranges S, Navas-Acien A, Rayman MP, Guallar E. Selenium status and cardiometabolic health: state of the evidence. Nutr Metab Cardiovasc Dis. (2010) 20:754-60. doi: 10.1016/j.numecd.2010.10.001

65. Kozat S, Gunduz H, Deger Y, Mert N, Yoruk I, Sel T. Studies on serum alphatocopherol, selenium levels and catalase activities in lambs with white muscle disease. Bull-Vet Inst Pulawy. (2007) 51:281.

66. Latimer KS. Duncan and Prasse's Veterinary Laboratory Medicine: Clinical Pathology. New York, NY: John Wiley \& Sons (2011).

Conflict of Interest: The authors declare that the research was conducted in the absence of any commercial or financial relationships that could be construed as a potential conflict of interest.

Publisher's Note: All claims expressed in this article are solely those of the authors and do not necessarily represent those of their affiliated organizations, or those of the publisher, the editors and the reviewers. Any product that may be evaluated in this article, or claim that may be made by its manufacturer, is not guaranteed or endorsed by the publisher.

Copyright (c) 2021 Ha, Kang, Han, Lee, Chung, Kim and Park. This is an open-access article distributed under the terms of the Creative Commons Attribution License (CC $B Y)$. The use, distribution or reproduction in other forums is permitted, provided the original author(s) and the copyright owner(s) are credited and that the original publication in this journal is cited, in accordance with accepted academic practice. No use, distribution or reproduction is permitted which does not comply with these terms. 